\title{
Germination and seedling growth of barley as affected by Artemisia annua water extract
}

\author{
Mazen Salman $^{1 *}$, Naser Salameh ${ }^{2}$, Saeid Abu-Romman ${ }^{3}$ \\ ${ }^{1}$ Palestine Technical University-Kadoorie, P.O. Box 7, Tulkarm, Palestine \\ ${ }^{2}$ Department of Plant Production, Faculty of Agriculture, Mutah University, Karak 61710, Jordan \\ ${ }^{3}$ Department of Biotechnology, Faculty of Agricultural Technology, Al-Balqa' Applied University, Al-Salt 19117, \\ Jordan
}

*Correspondence: salman_mazen@daad-alumni.de

\begin{abstract}
Laboratory and greenhouse pot experiments were conducted to assess the allelopathic effects of Artemisia annua water extract on germination and growth of barley. Lower concentrations of $A$. annua water extract $(0.5$ and $1.0 \%)$ did not affect the germination of barley seeds. However, higher concentrations (1.5-3.5 \%) resulted in significant reductions in the germination percentage. Seedling growth of barley was also affected by A. annua water extract. Both shoot and root lengths were negatively affected by A. annua water extract and the degree of inhibition was concentration dependent. When barley seedlings were subjected to $0.5 \%$ extract concentration, shoot length was inhibited by $6 \%$ while root length showed $18.5 \%$ inhibition over control seedlings. The lowest shoot and root lengths were recorded at 3.0 and $3.5 \%$ water extract. At $0.5 \%$ extract concentration, shoot and root fresh and dry weights were significantly unaffected compared with the control. Shoot fresh weight was significantly unaltered when seedlings were treated with $1.0 \%$ extract. However, at the same concentration root fresh weight, shoot dry weight, and root dry weight were inhibited by $44.7,33.3$, and $40 \%$, respectively. The present results confirmed that root growth (length and weight) was more sensitive to $A$. annua water extract than shoot growth. The present results also indicated the presence of water soluble allelochemicals in $A$. annua that are able to inhibit growth of barley.
\end{abstract}

Keywords: Artemisia annua, barley, germination, growth inhibition, water extract.

\section{Introduction}

Allelopathy, as an ecological phenomenon, refers to the positive or negative impacts of one plant species (as well as microorganisms) on the germination, growth, and physiological functions of other plant species through the release of phytochemical compounds (allelochemicals) into the environment (Rice, 1984; Weir et al., 2004; Inderjit et al., 2006). Allelochemicals are produced by any organ of the plant and are mainly secondary metabolites, such as flavonoids, alkaloids, tannins, phenolic acids, lignins, coumarins, and terpenoids (Inderjit and Duke, 2003; Li et al., 2010).

These chemicals vary among plant species and organs and are released into the environment by different processes; root exudation, volatilization, leaching, and tissue decomposition in soil (Parvez et al., 2004; Gniazdowska and Bogatek, 2005). Allelopathic activity has been reported in several herbal and medicinal plants, due to the array of active phytochemicals produced (Khanh et al., 2005; Sodaeizadeh et al., 2009; Abu-Romman et al., 2015).

Artemisia annua L (Asteraceae) is an annual medicinal plant widely distributed around the world and used in folk medicine to treat different ailments. A. апnиa is rich in terpenoids, phenols, flavonoids, and other shikimate pathway metabolites (Brown, 2010; Carbonara et al., 2012). This plant is a major source of the sesquiterpene lactone artimisinin, which is one of the most efficient drugs used in the treatment of the infectious disease malaria (van der Kooy and Sullivan, 2013). In vitro studies performed with $A$. апnua also showed that this medicinal plant exhibits other therapeutic properties.
It has been reported that $A$. апnиа possesses anticancer activity (Lai et al., 2013). Moreover, some studies indicated that $A$. annua tea infusions were highly effective against HIV (Wu et al., 2001; Lubbe et al., 2012).

Some reports have demonstrated the allelopathic nature of A. annua and its secondary metabolite artemisinin. In a field study, Lydon et al. (1997) reported growth inhibition of soybean and maize by incorporating A. annua leaves into soil. Similar results were shown by Delabays et al. (2008). The phytotoxic nature of artimisinin was first reported by Duke et al. (1987). Germination of lettuce and mung bean were shown to be inhibited in response to artimisinin (Chen and Leather, 1990; Chen et al., 1991; Panamanik et al., 2008; Jessing et al., 2014). The present study intended to further investigate the impacts of $A$. апnиa water extract on germination and seedling growth of barley.

\section{Results and Discussion}

The allelopathic potential of $A$. апnиa water extract on the germination of barley three days after treatment is shown in Fig 1 and 2. At low concentrations (0.5 and $1.0 \%)$, the germination of barley seeds was not significantly affected compared to control. However, at 1.5 and $2.0 \%$ of water extract, the germination was significantly reduced and scored 65.00 and $46.67 \%$, respectively. The lowest germination percentages $(<10 \%)$ were recorded when barley seeds were treated with 2.5-3.5\% of A. апnиa water extract (Fig 1). Allelopathic action of leaf tissues and extract fractions were previously reported in A. аппиа and other Artemisia species 
Table 1.The effect of different concentrations of water extract of Artemisia annua on shoot and root lengths (cm) of barley seedlings. Data are presented as the mean \pm SD. Values with the same letter are not significantly different as determined by Tukeys HSD test at $\mathrm{P}<0.05$

\begin{tabular}{lcc}
\hline Extract concentration $(\%)$ & Shoot length $(\mathrm{cm})$ & Root length $(\mathrm{cm})$ \\
\hline 0 & $14.09 \pm 1.74^{\mathrm{a}}$ & $9.37 \pm 1.33^{\mathrm{a}}$ \\
0.5 & $13.25 \pm 2.61^{\mathrm{ab}}$ & $7.63 \pm 1.02^{\mathrm{b}}$ \\
1.0 & $11.58 \pm 2.73^{\mathrm{b}}$ & $6.47 \pm 0.99^{\mathrm{c}}$ \\
1.5 & $9.24 \pm 3.32^{\mathrm{c}}$ & $5.01 \pm 0.89^{\mathrm{d}}$ \\
2.0 & $7.09 \pm 2.44^{\mathrm{d}}$ & $3.08 \pm 1.15^{\mathrm{e}}$ \\
2.5 & $5.87 \pm 2.22^{\mathrm{de}}$ & $2.51 \pm 1.15^{\mathrm{e}}$ \\
3.0 & $3.97 \pm 1.62^{\mathrm{ef}}$ & $1.40 \pm 1.04^{\mathrm{f}}$ \\
3.5 & $2.73 \pm 1.37^{\mathrm{f}}$ & $1.33 \pm 0.60^{\mathrm{f}}$ \\
\hline
\end{tabular}

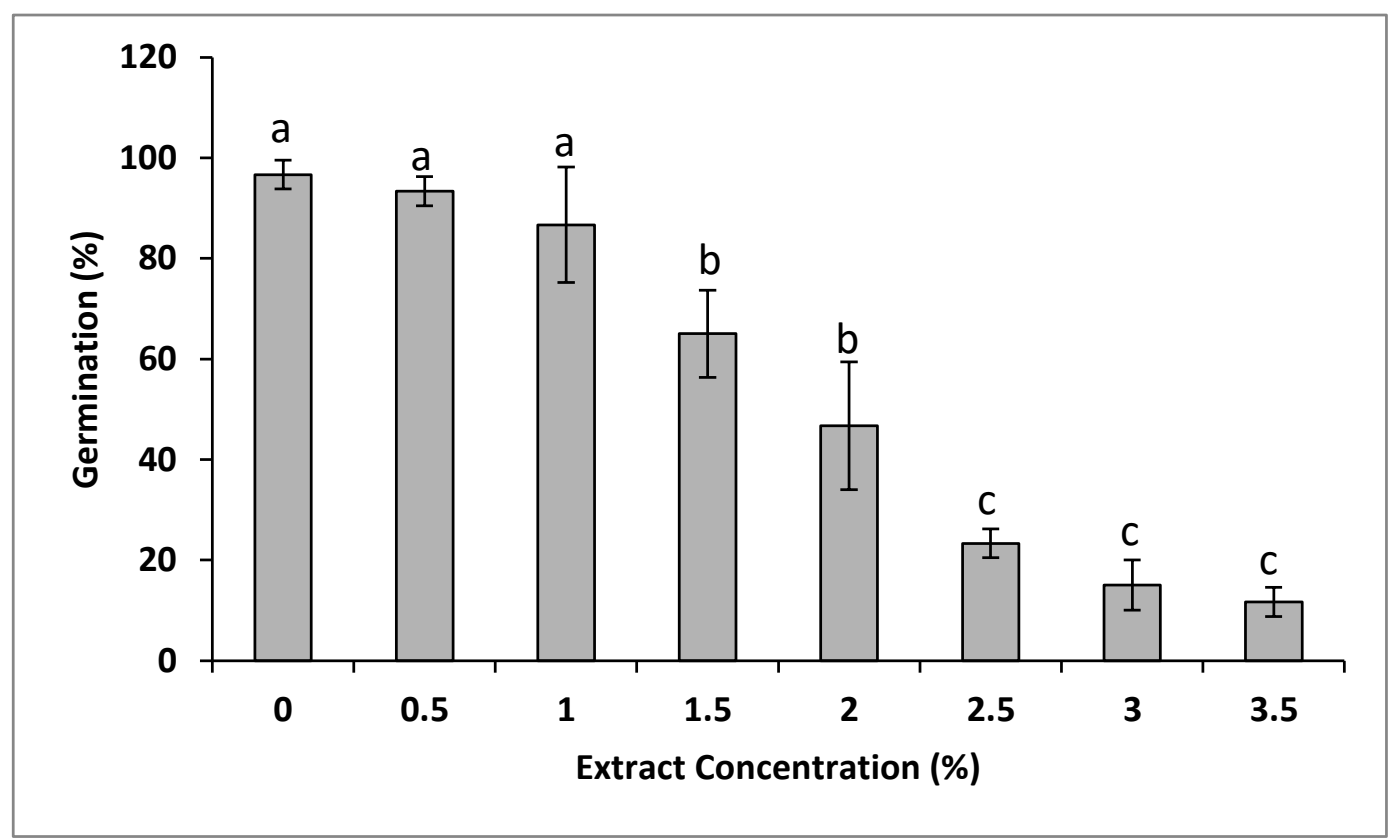

Fig 1. The effect of different concentrations of water extract of Artemisia annua on germination percentage of barley. Data are presented as the mean $\pm \mathrm{SD}$. Values with the same letter are not significantly different as determined by LSD test.

(Passim and Rodrigues, 1999; Delabays et al., 2008; Panamanik et al., 2008; Kegode et al., 2012; Jessing et al., 2014).

The observed reduction in barley germination under treatment of $A$. апnиa water extract could be attributed to the presence of water-soluble inhibitory allelochemicals. Several phytotoxins have been identified in A. апnиa (Jessing et al., 2014). Artemisinin, a highly oxygenated sesquiterpene of $A$. апnиа, was found to inhibit germination of different plant species (Duke et al., 1987; Chen et al., 1991; Lydon et al., 1997). Allelochemicals are reported to inhibit and delay the germination process by altering membrane permeability, mitochondrial respiration, enzymatic activities, and protein synthesis (Ferreira and Aquila, 2000; Kato-Noguchi et al., 2010; Ertani et al., 2016; Ozaki and Kato-Noguchi, 2016).

A pot experiment was conducted under greenhouse conditions to explore the allelopathic influence of $A$. апnиa water extract on the seedling growth of barley after one week of treatment.

Both shoot and root lengths were negatively affected by $A$. апnиa water extract and the degree of inhibition due to the extract increased with increasing extract concentration (Table 1). Similar effects were reported by Mallik et al. (2015) of Artemisia dubia on wheat and field mustard.

When barley seedlings were subjected to $0.5 \%$ extract concentration, shoot length was inhibited by $6 \%$ while root length showed $18.5 \%$ inhibition compared to control seedlings. The lowest shoot and root lengths were recorded at 3.0 and $3.5 \%$ water extract. The data in Table 1 illustrated clearly that root length was more affected by A. аnnua water extract compared to shoot length.

Root and shoot elongation of lettuce were found to be inhibited by artemisinin in a dose-dependent manner (Yan et al., 2015). The inhibitory action of artemisinin on target species growth could be attributed to the overproduction of reactive oxygen species and subsequence lipid peroxidation and arrested cell division (Dayan et al., 1999; Yan et al., 2015). Moreover, artemisinin was reported to possess strong anti-algal activity against Microcystis aeruginosa (Ni et al., 2012).

At $0.5 \%$ extract concentration, shoot and root fresh and dry weights were significantly unaffected compared with the control plants (Table 2). Shoot fresh weight was significantly unaltered when seedlings were treated with $1.0 \%$ extract. However, at the same concentration root fresh weight, shoot dry weight, and root dry weight were inhibited by $44.7 \%$, $33.3 \%$, and $40 \%$, respectively. Growth parameters measured in Table 2 generally showed reduction with elevated extract concentrations. Similarly, Moussavi-Nik et al. (2011) reported reduction in fresh and dry weights of Plantago ovate in response to treatment with $A$. аnnua water extract. The results in Figure 1 and Table 1 confirmed that root growth (length and weight) was more sensitive to putative allelochemicals present in $A$. аппиа water extract than shoot 
Table 2. The effect of different concentrations of water extract of Artemisia annua on fresh and dry weights (g) and chlorophyll content of barley seedlings. Data are presented as the mean \pm SD. Values with the same letter are not significantly different as determined by Tukeys HSD test at $\mathrm{P}<0.05$.

\begin{tabular}{|c|c|c|c|c|c|}
\hline \multirow{2}{*}{ Extract concentration $(\%)$} & \multicolumn{2}{|c|}{ Fresh weight (g) } & \multicolumn{2}{|l|}{ Dry weight (g) } & \multirow{2}{*}{$\begin{array}{l}\text { Chlorophyll } \\
\text { content }\end{array}$} \\
\hline & Shoot & Root & Shoot & Root & \\
\hline 0 & $0.64 \pm 0.09^{\mathrm{a}}$ & $0.47 \pm 0.11^{\mathrm{a}}$ & $0.06 \pm 0.009^{\mathrm{a}}$ & $0.037 \pm 0.003^{\mathrm{a}}$ & $30.13 \pm 2.8^{\mathrm{a}}$ \\
\hline 0.5 & $0.61 \pm 0.11^{\mathrm{a}}$ & $0.42 \pm 0.10^{\mathrm{a}}$ & $0.05 \pm 0.009^{\mathrm{ab}}$ & $0.035 \pm 0.004^{\mathrm{a}}$ & $29.90 \pm 2.1^{\mathrm{a}}$ \\
\hline 1.0 & $0.54 \pm 0.04^{\mathrm{a}}$ & $0.26 \pm 0.07^{b}$ & $0.04 \pm 0.008^{\mathrm{bc}}$ & $0.022 \pm 0.005^{\mathrm{b}}$ & $27.23 \pm 1.4^{\mathrm{a}}$ \\
\hline 1.5 & $0.52 \pm 0.05^{\mathrm{ab}}$ & $0.20 \pm 0.06^{\mathrm{bc}}$ & $0.04 \pm 0.007^{\mathrm{bcd}}$ & $0.018 \pm 0.006^{\mathrm{b}}$ & $28.29 \pm 1.7^{\mathrm{a}}$ \\
\hline 2.0 & $0.36 \pm 0.05^{\mathrm{bc}}$ & $0.11 \pm 0.06^{\mathrm{cd}}$ & $0.03 \pm 0.004^{\mathrm{cd}}$ & $0.015 \pm 0.003^{b}$ & $29.54 \pm 2.0^{\mathrm{a}}$ \\
\hline 2.5 & $0.29 \pm 0.10^{c}$ & $0.08 \pm 0.04^{\mathrm{cd}}$ & $0.02 \pm 0.008^{\mathrm{de}}$ & $0.007 \pm 0.004^{c}$ & $29.49 \pm 2.3^{\mathrm{a}}$ \\
\hline 3.0 & $0.22 \pm 0.13^{\mathrm{cd}}$ & $0.03 \pm 0.03^{\mathrm{d}}$ & $0.01 \pm 0.007^{\mathrm{ef}}$ & $0.002 \pm 0.002^{\mathrm{c}}$ & $29.76 \pm 1.6^{\mathrm{a}}$ \\
\hline 3.5 & $0.08 \pm 0.04^{\mathrm{d}}$ & $0.02 \pm 0.01^{\mathrm{d}}$ & $0.01 \pm 0.004^{\mathrm{f}}$ & $0.002 \pm 0.003^{\mathrm{c}}$ & $27.49 \pm 1.3^{\mathrm{a}}$ \\
\hline
\end{tabular}
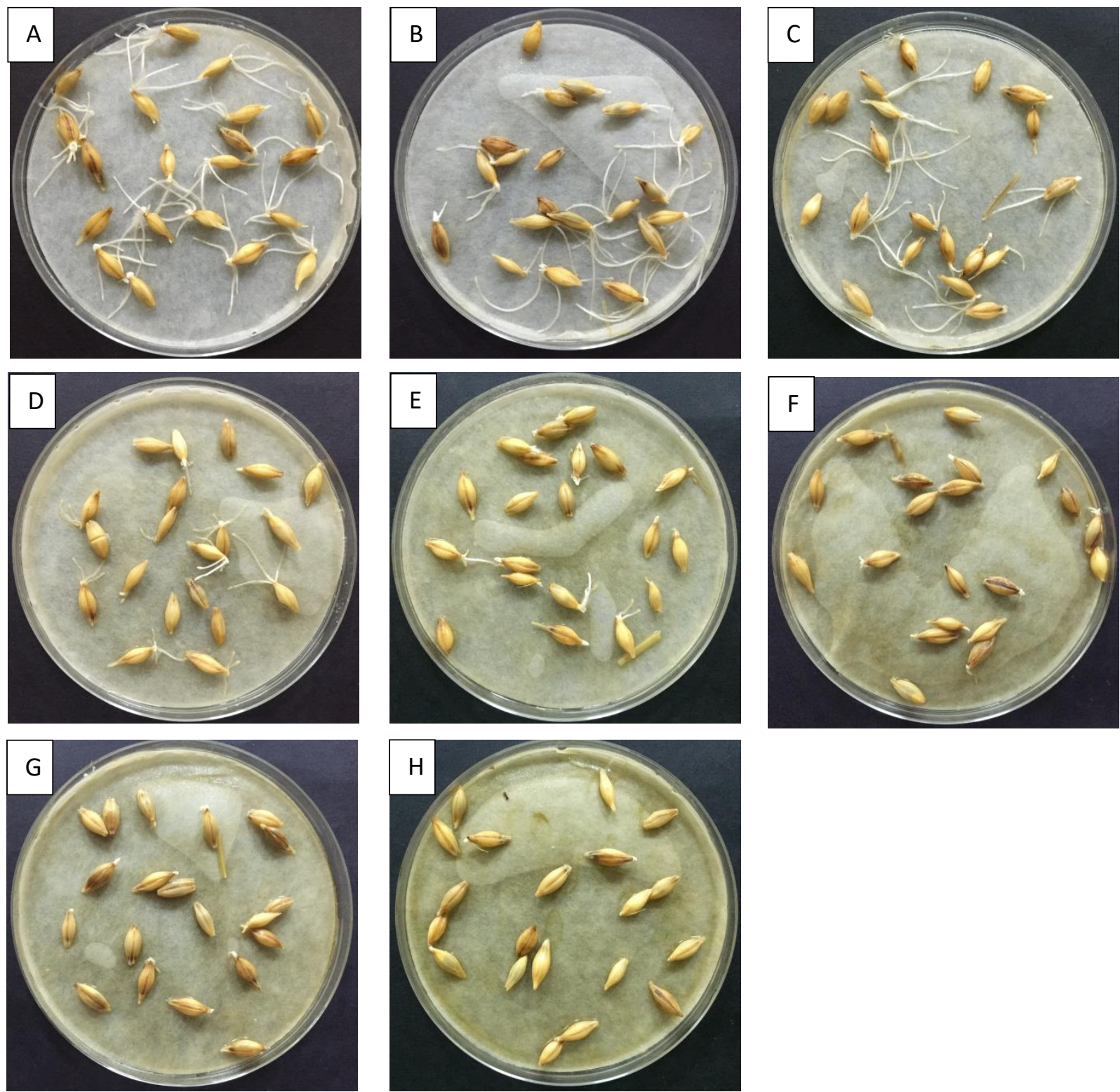

Fig 2. The effect of different concentrations of water extract of Artemisia annua on germination of barley seeds were A: control, B: $0.5 \%$, C: $1.0 \%$, D: $1.5 \%$, E $2.0 \%$, F: $2.5 \%$, G: $3.0 \%$ and H: $3.5 \%$. 


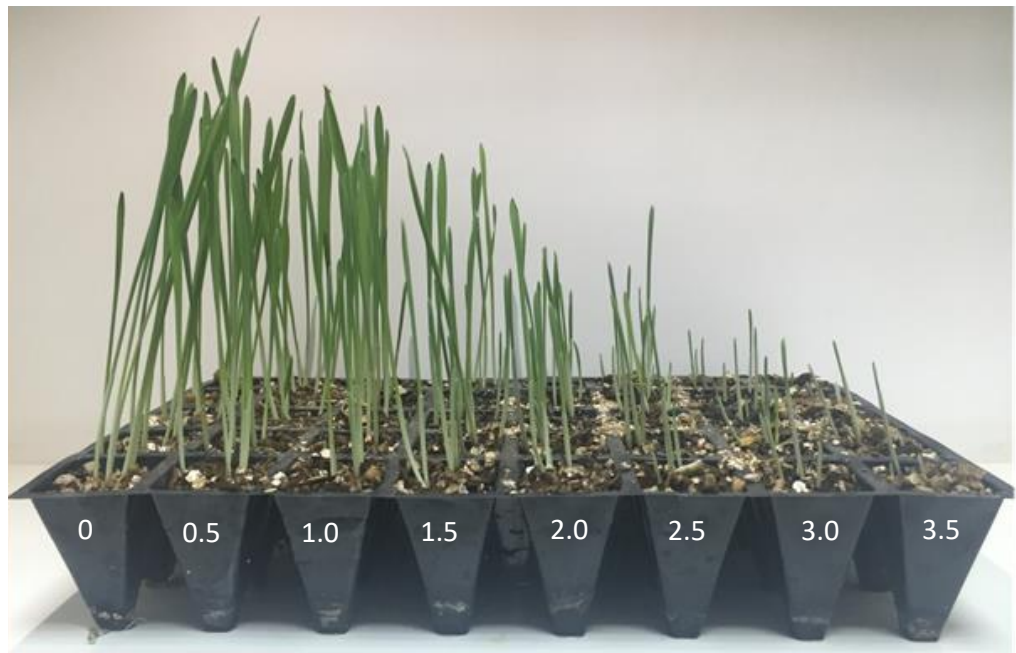

Fig 3. The effect of different concentrations (0.0, 0.5, 1.0, 1.5, 2.0, 2.5, 3.0 and 3.5\%) of water extract of Artemisia annua on growth of barley seedlings.

growth. Similar observations were previously reported (Khan and Kato-Noguchi, 2016). A study conducted by AbuRomman (2011) showed that water extract of Achillea biebersteinii (Asteraceae) greatly inhibited root growth compared to shoot growth of pepper. The highest root sensitivity to allelochemicals could be attributed to the direct contact of the root system to these toxic phytochemicals and the high permeability of root tissues (Nishida et al., 2005; Abu-Romman and Ammari, 2015; Abd El-Gawwad, 2016) Allelochemical stress was reported to reduce chlorophyll content in different affected species (Gulzar and Siddiqui, 2014; Sarkar and Chakraborty, 2015; Abu-Romman, 2016). However, in the present study total chlorophyll content of barley seedlings was not significantly affected in response to A. аnnua water extract (Table 2). This result is in line with the findings of Benyas et al. (2010), who showed that water extract of the weed Xanthium strumarium did not affect total chlorophyll content of lentil seedlings.

\section{Materials and Methods}

\section{Plant material and extract preparation}

Leaves of Artemisia annua were collected from Tulkarm in the West Bank $\left(32^{\circ} 18.6222^{\prime} \mathrm{N}, 35^{\circ} 1.7178^{\prime} \mathrm{E}, 117 \mathrm{~m}\right.$ above sea level). The collected leaves were dried at $65^{\circ} \mathrm{C}$ for $48 \mathrm{~h}$ until constant weight and ground to a fine powder. A $10 \%$ (w/v) extract was prepared by soaking $10 \mathrm{~g}$ of the powder in $100 \mathrm{~mL}$ distilled water for $24 \mathrm{~h}$ on a horizontal shaker at 110 rpm. The extract was filtered through a double layer of cheesecloth and then filtered through Whatman no 1 filter paper. The extract was stored at $4^{\circ} \mathrm{C}$ until use. Different concentrations $(0.5,1.0,1.5,2.0,2.5,3.0$ and $3.5 \%)$ of the extract were used in laboratory and green house experiments.

\section{Laboratory experiment}

Twenty seeds of barley (Hordeum vulgare L.) were spread on a filter paper in $9 \mathrm{~cm}$ Petri dishes. For each petri plate $3 \mathrm{~mL}$ of each concentration was added. The plates were sealed with parafilm and incubated at $25^{\circ} \mathrm{C}$ in the dark. After 3 days, final germination percentages were recorded. Seeds were considered germinated if the root length exceeds half the length of the seed. Treatments were arranged in a completely randomized design with three replications and the experiment was repeated three times.

\section{Pot experiment}

Seedling cell trays $(5 \mathrm{~cm}$ in diameter eye) were filled with peat moss vermiculite mixture $(2: 1 \mathrm{v} / \mathrm{v})$. Five barley seeds were sown in each cell before irrigation with $A$. аппиа aqueous extracts. Each cell was irrigated with $10 \mathrm{~mL}$ of each concentration. Controls were irrigated with tap water. One week after incubation at $25^{\circ} \mathrm{C}$, number of germinated seeds was recorded. Shoot and root lengths were measured. After recording the fresh weight of the germinated seedlings, the seedlings were placed in a drying oven at $65^{\circ} \mathrm{C}$ for dry weight measurement. In addition to that, chlorophyll content was measured using Chlorophyll Meter SPAD-502Plus. Treatments were arranged in a randomized complete block design with three replications and the experiment was repeated three times.

\section{Statistical analysis}

All experiments were done in triplicates and repeated three times. Statistical analysis was done using XIStat (Adinosoft). Significant differences were computed using ANOVA after Tukeys HSD test at $\mathrm{P}<0.05$

\section{Conclusion}

Allelopathic effect $A$. апnиa water extract toward barley was observed in the current study. Water extract of this medicinal plant inhibited germination of barley seeds. Moreover, seedling growth was also negatively affected by treatment with $A$. annua water extract in a concentration-dependent manner. These results indicated the presence of water soluble allelochemicals in A. апnиа. The medicinal plant $A$. аппиа must be examined for its allelopathic action on other economic crops and noxious weeds, particularly under field conditions. Moreover, further study is needed to characterize potential allelochemicals present in different plant parts of $A$. annua. 


\section{Acknowledgments}

The authors would like to thank Palestine Technical University (PTUK) for the support to carry out this research. Thanks are due to Ms Basima Aburumaileh and Eng Mohammed Jawbrih for their assistance.

\section{References}

Abd El-Gawad AMA (2016) Chemical constituents, antioxidant and potential allelopathic effect of the essential oil from the aerial parts of Cullen plicata. Ind Crop Prod. 80:36-41.

Abu-Romman S (2011) Allelopathic potential of Achillea biebersteinii Afan. (Asteraceae). World Appl Sci J. 15(7):947-952.

Abu-Romman S, Ammari T (2015) Allelopathic effect of Arundo donax, a mediterranean invasive grass. Plant Omics. 8(4):287.

Abu-Romman SM, Haddad MA, Al-Hadid KJ (2015) The potential allelopathic effects of Varthemia iphionoides and the identification of phenolic allelochemicals. Jordan J Biol Sci. 8(4):301-306.

Abu-Romman S (2016) Differential allelopathic expression of different plant parts of Achillea biebersteinii. Acta Biol Hung. 67(2):159-168.

Benyas E, Hassanpouraghdam M.B, Zehtab Salmasi S, Khatamian Oskooei OS (2010) Allelopathic effects of Xanthium strumarium L. shoot aqueous extract on germination, seedling growth and chlorophyll content of lentil (Lens culinaris Medic.). Rom Biotech Lett. 15(3):5223-5228.

Brown GD (2010) The biosynthesis of artemisinin (Qinghaosu) and the phytochemistry of Artemisia annua L.(Qinghao). Molecules. 15(11):7603-7698.

Carbonara T, Pascale R, Argentieri MP, Papadia P, Fanizzi FP, Villanova L, Avato P (2012) Phytochemical analysis of a herbal tea from Artemisia аппиа L. J Pharmaceut Biomed. 62:79-86.

Chen PK, Leather GR (1990) Plant-growth regulatory activities of artemisinin and its related compounds. J Chem Ecol. 16:1867-1876.

Chen PK, Polatnick M, Leather G (1991) Comparative study on artemisinin, 2,4-D, and glyphosate. J Agric Food Chem. 39:991-994.

Delabays N, Slacanin I, Bohren C (2008) Herbicidal potential of artemisinin and allelopathic properties of Artemisia annua L: from the laboratory to the field. J Plant Dis Protect. Special Issue XXI:317-322.

Dayan FE, Hernandez A, Allen SN, Moraes RM, Vroman JA, Avery MA, Duke SO (1999) Comparative phytotoxicity of artemisinin and several sesquiterpene analogues. Phytochemistry. 50:607-614

Duke SO, Vaughn KC, Croom Jr EM, Elsohly HN (1987). Artemisinin, a constituent of annual wormwood (Artemisia апnиa), is a selective phytotoxin. Weed Sci. 35:499-505.

Ertani A, Pizzeghello D, Francioso O, Tinti A, Nardi S (2016) Biological activity of vegetal extracts containing phenols on plant metabolism. Molecules. 21(2):205.

Ferreira AG, Aquila MEA (2000) Allelopathy: An emerging area of ecophysiology. Braz J Plant Physiol. 12:175-204.

Gniazdowska A, Bogatek R (2005) Allelopathic interactions between plants. Multi-site action of allelochemicals. Acta Physiol Plant. 27:395-407.

Gulzar A, Siddiqui MB (2014) Evaluation of allelopathic effect of Eclipta alba (L.) Hassk on biochemical activity of Amaranthus spinosus L., Cassia tora L. and Cassia sophera L. Afr J Environ Sci Technol. 8:1-5.

Inderjit, Callaway RM, Vivanco JM (2006) Can plant biochemistry contribute to understanding of invasion ecology? Trends Plant Sci.11:574-580.

Inderjit, Duke SO (2003) Ecophysiological aspects of allelopathy. Planta. 217:529-539.

Jessing KK, Duke SO, Cedergreeen N (2014) Potential ecological roles of artemisinin produced by Artemisia annua L. J Chem Ecol. 40(2):100-117.

Kato-Noguchi H, Macías FA, Molinillo JMG (2010) Structure activity relationship of benzoxazinones and related compounds with respect to the growth inhibition and a-amylase activity in cress seedlings. J Plant Physiol. 167:1221-1225.

Kegode GO, Ciernia MG, Vlieger DB (2012) Allelopathic potential of Artemisia biennis (biennial wormwood). Agr Sci. 3(4):582-587.

Khanh TD, Hong NH, Xuan TD, Chung IM (2005) Paddy weed control by medicinal and leguminous plants from Southeast Asia. Crop Prot. 24:421-431.

Khan MSI, Kato-Noguchi H (2016) Assessment of allelopathic potential of Couroupita guianensis Aubl. Plant Omics. 9(2):115-120.

Lai HC, Singh NP, Sasaki T (2013) Development of artemisinin compounds for cancer treatment. Invest New Drugs. 31:230-246.

Li Z-H, Wang Q, Ruan X, Pan C-D, Jiang D-A (2010) Phenolics and plant allelopathy. Molecules.15(12):8933-52.

Lubbe A, Seibert I, Klimkait T, Van Der Kooy F (2012) Ethnopharmacology in overdrive: the remarkable anti-HIV activity of Artemisia annua. J Ethnopharmacol. 141:854859.

Lydon J, Teasdale JR, Chen PK (1997) Allelopathic activity of annual wormwood (Artemisia annua) and the role of artemisinin. Weed Sci. 45:807-811.

Mallik BBD, Acharya BD, Saquib M, Chettri MK (2015) Allelopathic effect of Artemisia dubia extracts on seed germination and seedling growth of some weeds and winter crops. Ecoprint: Int J Ecol. 21:23-30.

Moussavi-Nik SM, Bijeh keshavarzi MH, Ali Bakhtiari Gharibdosti AB (2011) Effect of aqueous extracts of allelopathic Artemisia annua on germination and early growth of Isabgol (Plantago ovate). Ann Biol Res. 2(6):687-691.

Ni L, Acharya K, Hao X, Li S (2012) Isolation and identification of an anti-algal compound from Artemisia аппиа and mechanisms of inhibitory effect on algae. Chemosphere. 88(9):1051-1057.

Nishida N, Tamotsu S, Nagata N, Saito C, Saka A (2005) Allelopathic effects of volatile monoterpenoids produced by Salvia leucophylla: inhibition of cell proliferation and DNA synthesis in the root apical meristem of Brassica campestris seedlings. J Chem Ecol. 31:1187-1203.

Ozaki Y, Kato-Noguchi H (2016) Effects of benzoxazinoids in wheat residues may inhibit the germination, growth and gibberellin-induced $\alpha$-amylase activity in rice. Acta Physiol Plant. 38(1):1-5.

Panamanik RC, Chikkaswamy BK, Roy DG, Panamanik A, Kumar V (2008) Effects of biochemicals of Artemisia annua in plants. J Pierre Fauchard Acad. 21:11-18.

Parvez SS, Parvez MM, Fujii Y, Gemma H (2004) Differential allelopathic expression of bark and seed of Tamarindus indica L. Plant Growth Regul. 42:245-252.

Passim T, Rodrigues BN (1999) Pioneers of allelopathy IX. Fernando L.S. de Almeida. Allelopathy J. 6(2):187-189. 
Rice EL (1984) Allelopathy. 2nd. edn. Orlando, Academic Press.

Sarkar E, Chakraborty P (2015) Allelopathic effect of Amaranthus spinosus Linn. on growth of rice and mustard. J Trop Agr. 53(2):139-148.

Sodaeizadeh H, Rafieiolhossaini M, Havlík J, Van Damme P (2009) Allelopathic activity of different plant parts of Peganum harmala L. and identification of their growth inhibitors substances, Plant Growth Regul. 59:227-236.

van der Kooy F, Sullivan SE (2013) The complexity of medicinal plants: The traditional Artemisia annua formulation, current status and future perspectives. J Ethnopharmacol. 150 (1):1-13.
Weir TL, Park SW, Vivanco JM (2004) Biochemical and physiological mechanisms mediated by allelochemicals. Curr Opin Plant Biol. 7:472-479.

Wu TS, Tsang ZJ, Wu PL, Lin FW, Li CY, Teng CM, Lee KH (2001) New constituents and antiplatelet aggregation and anti-HIV principles of Artemisia capillaries. Bioorgan Med Chem. 9:77-83.

Yan ZQ, Wang DD, Ding L, Cui HY, Jin H, Yang XY, Yang JS, Qin B (2015) Mechanism of artemisinin phytotoxicity action: Induction of reactive oxygen species and cell death in lettuce seedlings. Plant Physiol Bioch. 88:53-59. 